\title{
Doktor Jan Roch Raum w świetle dokumentów z zasobu Archiwum Państwowego w Warszawie
}

\begin{abstract}
Doctor Jan Roch Raum - in the light of documents in the asset of the State Archive in Warsaw

Summary

Doctor Jan Roch Raum (1854-1918) was a surgeon from Warsaw who most of his professional life was associated with the Przemienienie Pańskie Hospital, where he was the Chief Physician. He left behind a small archival legacy, kept in the collection "Zbiór Jana Rauma", 72/1275, 1859-1923. The analysis of these documents, and others records of different provenance, is an attempt to present this figure from a different perspective than the official biographies. It allows to get to know his family, his career, and the bright and dark sides of the doctor's life, like letters from grateful patients, complaints of the families of the victims of medical errors and the course of disciplinary proceedings. These documents are also a great source for researching the history of the Przemienienie Pańskie Hospital in Warsaw.
\end{abstract}

Słowa kluczowe: szpital Przemienienia Pańskiego w Warszawie, Jan Roch Raum, chirurg, sprawa dyscyplinarna, zbiór rodzinny, spuścizna

Keywords: Przemienienie Pańskie Hospital in Warsaw, Jan Roch Raum, surgeon, disciplinary case, family collection, legacy

Każdy badacz, poszukując dokumentów dotyczących interesującej go postaci, ma nadzieję na odnalezienie jego spuścizny w archiwum lub bibliotece, najlepiej uporządkowanej i opracowanej. Znacznie częściej okazuje się jednak, że poszukiwane dokumenty są rozproszone i przechowywane w rożnych instytucjach. Innym wariantem ww. przypadku są archiwalia przechowywane w jednej instytucji, ale 
w rożnych zespołach archiwalnych. Przykładem tego ostatniego są dokumenty dotyczące doktora Jana Rocha Rauma, Lekarza Naczelnego szpitala Przemienia Pańskiego w Warszawie, przechowywane w Archiwum Państwowym w Warszawie, w następujących zespołach archiwalnych:

- Zbiór Jana Rauma, nr zesp. 72/1275, 1859-1923

- Zbiór Korotyńskich, nr zesp. 72/201, 1767-1946

- Akta stanu cywilnego parafii rzymskokatolickiej św. Krzyża w Warszawie, nr zesp. 72/158, 1826-1934

- Akta stanu cywilnego parafii rzymskokatolickiej św. Floriana w Warszawie, nr zesp. 72/1328, 1901-1919

- Zbiór fotografii, nr zesp. 72/1606, XIX-1930

Niniejszy artykuł jest próbą zaprezentowania sylwetki doktora Jana Rauma, mając do dyspozycji archiwalia o różnej proweniencji, a nie jednolitą spuściznę.

Najwięcej informacji dotyczących doktora J. Rauma dostarcza zbiór rodzinny „Zbiór Jana Rauma”, nr zesp. 72/1275. Dokumenty należące do ww. zespołu zostały sporządzone w latach 1859-1923, a do Archiwum zostały przekazane w 1963 r. (Nab. 637/1963). Jest to zespół opracowany, posiadający inwentarz książkowy, obecnie dostępny w formie elektronicznej w aplikacji Zintegrowany System Informacji Archiwalnej (ZoSIA) ${ }^{1}$. Jego rozmiary są stosunkowe niewielkie: 39 jednostek archiwalnych i 0,37 metra bieżącego, przy czym doktora Jana Rauma dotyczą 32 jednostki, a pozostałe - Marii Raum. Archiwalia przechowywane w ww. zespole to druki, rękopisy, maszynopisy i liczna ikonografia. Dokumenty te stanowią odzwierciedlenie dorobku naukowego i kariery zawodowej oraz zainteresowań tego warszawskiego chirurga. Są to materiały wyjątkowe, ponieważ umożliwiają zapoznanie się z blaskami i cieniami życia lekarza przełomu XIX i XX w., jakim są nie tylko podziękowania od wdzięcznych pacjentów, ale także skargi od tych, którzy uznali, że ich bliscy zostali pokrzywdzeni.

Jan Roch Raum² (1854-1918) był chirurgiem, który swoje życie zawodowe związał ze szpitalem Przemienienia Pańskiego na Pradze.

${ }^{1}$ Zintegrowany System Informacji Archiwalnej ZoSIA to aplikacja przeznaczona do opracowania (ewidencji i inwentaryzacji) zbiorów archiwalnych na wszystkich poziomach ich hierarchicznej struktury - od całego archiwum aż po obiekt archiwalny. Zawiera również szybką i precyzyjną wyszukiwarkę danych. Narodowe Archiwum Cyfrowe: https://www.nac.gov.pl/archiwum-cyfrowe/systemy-i-infrastruktura-it/zosia/ [dostęp: 8.09.2019].

2 Jan Roch Raum (1854-1918), lekarz, chirurg, w latach 1899-1918 Lekarz Naczelny Szpitala Przemienienia Pańskiego w Warszawie - Polski Słownik Biograficzny, https://www.ipsb.nina.gov.pl/a/biografia/jan-roch-raum [dostęp: 8.09.2019]. 
Akta „Zbioru Jana Rauma” dotyczą głównie jego życia zawodowego, niewiele na podstawie ww. dokumentów można się dowiedzieć o życiu rodzinnym lub dzieciństwie. Tych informacji nie dostarcza również jednostka archiwalna „Raum Jan - lekarz”, przechowywana w „Zbiorze Korotyńskich”3 - ogromnej kolekcji varsavianistycznej, składającej się $\mathrm{w}$ dużej mierze $\mathrm{z}$ materiałów biograficznych. Wspomniane dokumenty dotyczące dr. Rauma stanowią głównie wycinki prasowe z lat 1891-1918, potwierdzające jedynie ogólnie znane aspekty życia doktora. W pewnym stopniu tę lukę wypełniają innego rodzaju archiwalia - np. jego akt urodzenia oraz akt małżeństwa rodziców. Z treści aktu urodzenia Jana Rocha Rauma sporządzonego w czerwcu 1855 r. w parafii św. Krzyża w Warszawie ${ }^{4}$ wynika, że jego rodzicami byli Jan Raum i Teofila z Adamowiczów. Dokument został sporządzony z pewnym opóźnieniem - bowiem Jan Roch Raum urodził się 16 sierpnia 1854 r. - prawdopodobnie spowodowanym nieobecnością ojca, który wtedy przebywał w Paryżu. Zawód Jana Rauma (ojca) został określony jako „Z własnych funduszy utrzymujący się”. Znacznie więcej informacji o rodzicach Jana Rocha Rauma dostarcza akt małżeństwa, sporządzony w 1851 r., również w warszawskiej parafii św. Krzyżas. $\mathrm{Z}$ jego treści wynika, że Johan Raum, kawaler kamerdyner (1. 41), urodził się w Nirenbergu w Bawarii, natomiast Teofila Adamowicz (1. 26), to panna służąca urodzona w Mohylewie. Oboje w momencie sporządzania aktu małżeństwa zamieszkiwali w Warszawie przy ul. Nowy Świat nr (hipoteczny) 1245. W aneksach do akt małżeństw z $1851 \mathrm{r}$. z parafii św. Krzyża przechowywany jest interesujący dokument, będący poświadczeniem tożsamości, stanu cywilnego i wieku obojga przyszłych małżonków ${ }^{6}$. Jego autor, generał Diakoff dodatkowo zaświadcza, że Johan Raum „przez przeciąg swej służby u mnie spełniał rozmaite, wkładane na niego obowiązki z najprzykładniejszą gorliwością i kilkakrotnie posyłany był do Dóbr moich Cesarstwie Rosyjskim leżących dla rozmaitych potrzeb, okazał się trzeźwym, pilnym, uczciwym i zdolnym"'. Kolejnych informacji o rodzinie Raumów dostarcza fotografia rodzinna ${ }^{8}$, sporządzona w okresie powstania

\footnotetext{
${ }^{3}$ Archiwum Państwowe w Warszawie (dalej: APW), Zbiór Korotyńskich, 72/201, sygn. XI-2061.

${ }^{4}$ APW, Akta stanu cywilnego parafii rzymskokatolickiej św. Krzyża w Warszawie (dalej: ASCK), 72/158, sygn. 28, k. 128v.

${ }^{5}$ APW, ASCK, sygn. 25, k. 373.

${ }^{6}$ Tamże, sygn. 71, k. 378.

7 Tamże.

${ }^{8}$ APW, Zbiór fotografii, nr zesp. 72/1606, sygn. 192.
} 


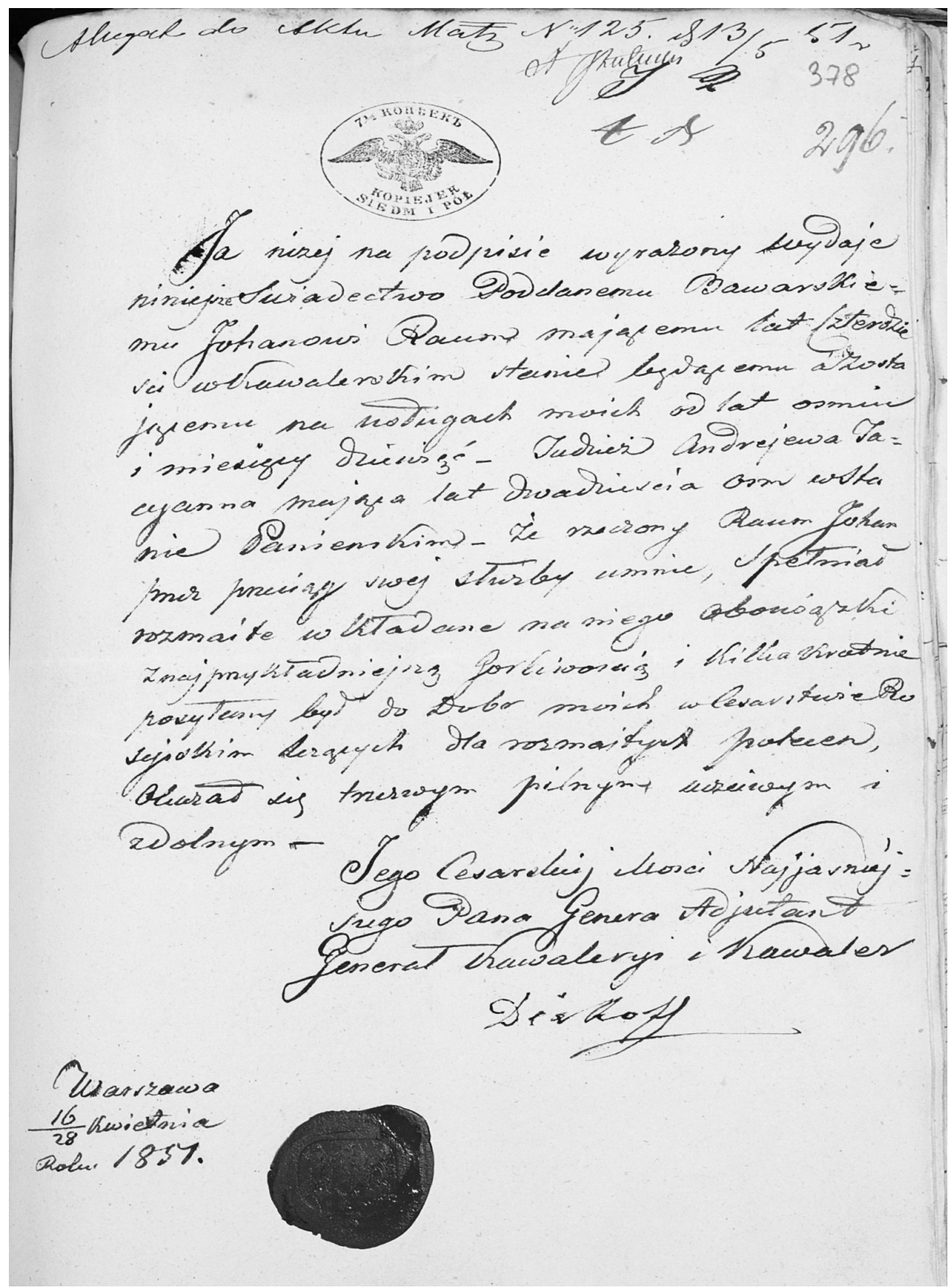

Ryc. 1. Pismo gen. Diakoffa poświadczające tożsamość rodziców dr. J. Rauma, 1851 r.

Źródło: Archiwum Państwowe w Warszawie. 


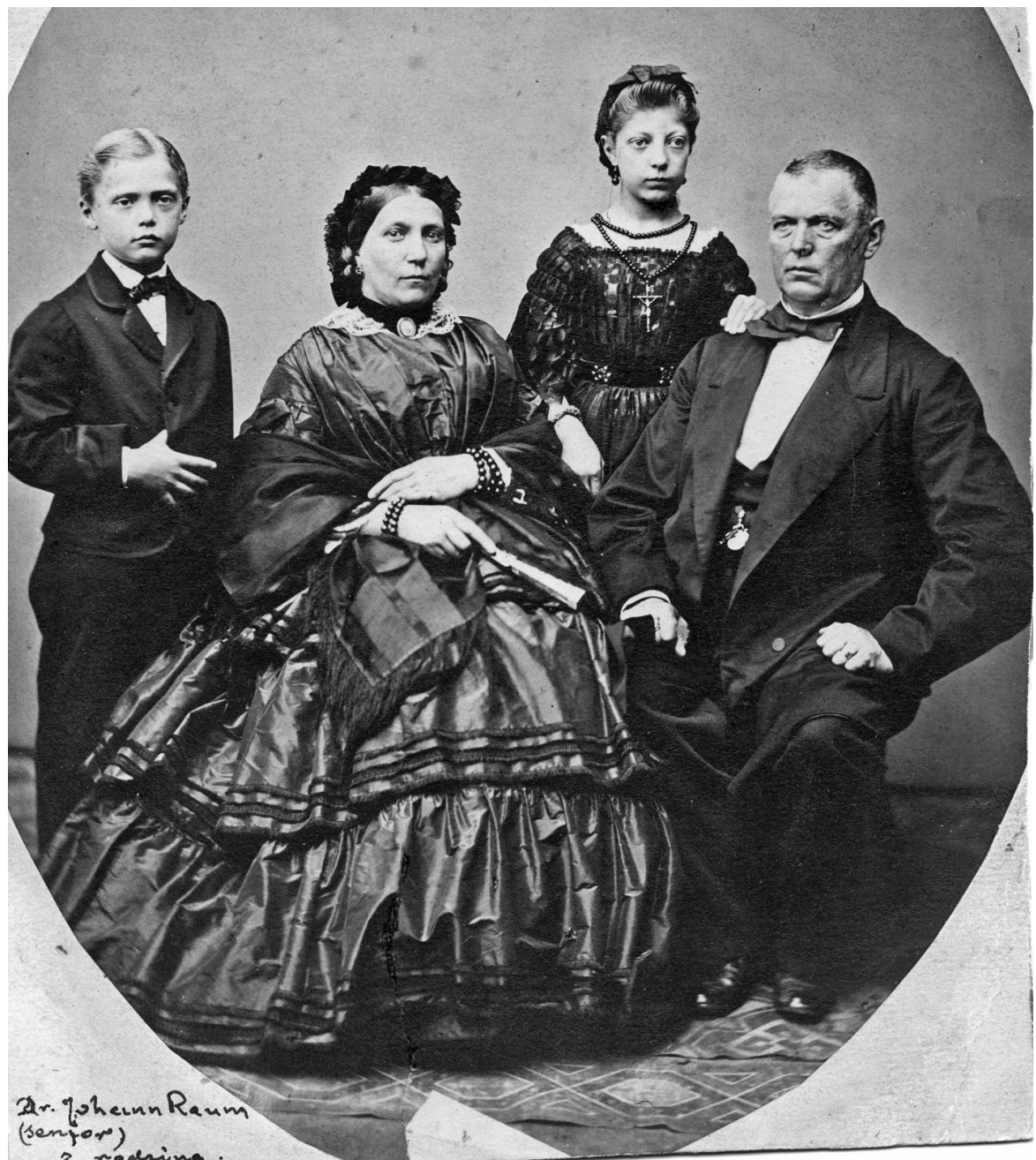

Ryc. 2. Jan Roch Raum w wieku dziecięcym z rodziną, bd.

Źródło: Archiwum Państwowe w Warszawie.

styczniowego (o czym świadczy np. biżuteria żałobna). Podpis, sporządzony znacznie później niż sama fotografia, sugeruje, iż przedstawia ona „Dr. Johanna Rauma (seniora) z rodziną”, co stoi w sprzeczności ze wspomnianymi dokumentami dotyczącymi Johana Rauma. Należy również wspomnieć o akcie zgonu dr. J. Rauma, sporządzonym w 1918 r. na Pradze ${ }^{9}$, w którym czytamy, że „dziś zmarł na Pradze przy

${ }_{9}$ APW, Akta stanu cywilnego parafii rzymskokatolickiej św. Floriana w Warszawie, nr zesp. 72/1328, sygn. 110, s. 469. 
ul. Panieńskiej pod numerem dziesiątym Roch Jan Raum lat sześćdziesiąt cztery, kawaler, naczelny lekarz Przemienienia Pańskiego, urodzony w Warszawie, syn Jana i Teofili z Adamowiczów”.

W aktach zespołu „Zbiór Jana Rauma” przechowywane są dokumenty typowe dla spuścizn archiwalnych po uczonych, czyli np. wydana w formie broszury publikacja „Z pracowni Patologii Ogólnej Cesarskiego Warszawskiego Uniwersytetu Przyczynek do nauki o nekrozie komórki przez Dra med. J. Rauma Asystenta tejże pracowni. Odbitka z Pamiętnika Towarzystwa Lekarskiego Warszaw. Rok 1893. Tom LXXXIX"10. Na uwagę zasługują również dwa zeszyty o wymiarach 22 x $18 \mathrm{~cm}$ zawierające notatki z wykładów z medycyny Jana Rauma, sporządzone w 1883 r. podczas studiów na Uniwersytecie w Dorpacie ${ }^{11}$. Pierwszy z nich liczy 28 kart, drugi - 15. Wszystkie notatki zostały sporządzone w języku niemieckim, a uwagę przyciągają odręczne ilustracje. Na niebieskiej okładce pierwszego z ww. zeszytów ${ }^{12}$, w białym polu przeznaczonym do wpisywania nazwy przedmiotu, widnieje „Raum” oraz „Dorpat 1883”, a na pierwszej stronie J. Raum umieścił cytat z pracy J.F. Dieffenbacha „oft muss anders geschnitten werden, als man es gelernt [...]"13, dowodzący, że zdawał sobie sprawę, iż wiedza uniwersytecka nie będzie odpowiedzią na wszystkie pytania, jakie staną w przyszłości przed nim, gdy będzie już praktykującym chirurgiem. Notatki przechowywane w omawianej jednostce dotyczą budowy i funkcjonowania tętnic (udowej, podkolanowej, piszczelowej przedniej, szyjnej zewnętrznej, językowej itp.). Następny z ww. zeszytów ${ }^{14}$ zawiera notatki dotyczące budowy stawów (kolanowego, nadgarstkowego, ramiennego, łokciowego itp.).

Dobrze zachowane są też świadectwa szkolne i dyplomy J. Rauma, przechowywane w jednostce archiwalnej o sygnaturze 18. Można tu znaleźć np. dyplom przyjęcia doktora medycyny Jana Rauma do grona członków czynnych Towarzystwa Lekarskiego Warszawskiego (1890 r. ${ }^{15} \mathrm{~W}$ ww. zbiorze archiwalnym przechowywane są również notatki doktora Rauma sporządzone w późniejszym okresie (1906-1916), dotyczące chirurgii, radiologii ran postrzałowych ${ }^{16}$. Niezwykle inte-

\footnotetext{
${ }^{10}$ APW, Zbiór Jana Rauma (dalej: ZJR), nr zesp. 72/1275, sygn. 1.

${ }^{11}$ APW, ZJR, sygn. 20, 21.

12 Tamże, sygn. 20.

${ }^{13}$ J.F. Dieffenbach, Die operative Chirurgie, Lipsk, 1845, k. 2.

${ }^{14}$ APW, ZJR, nr zesp. 72/1275, sygn. 1.

${ }^{15}$ Tamże, sygn. 18, k. 1-7.

${ }^{16}$ Tamże, sygn. 3.
} 


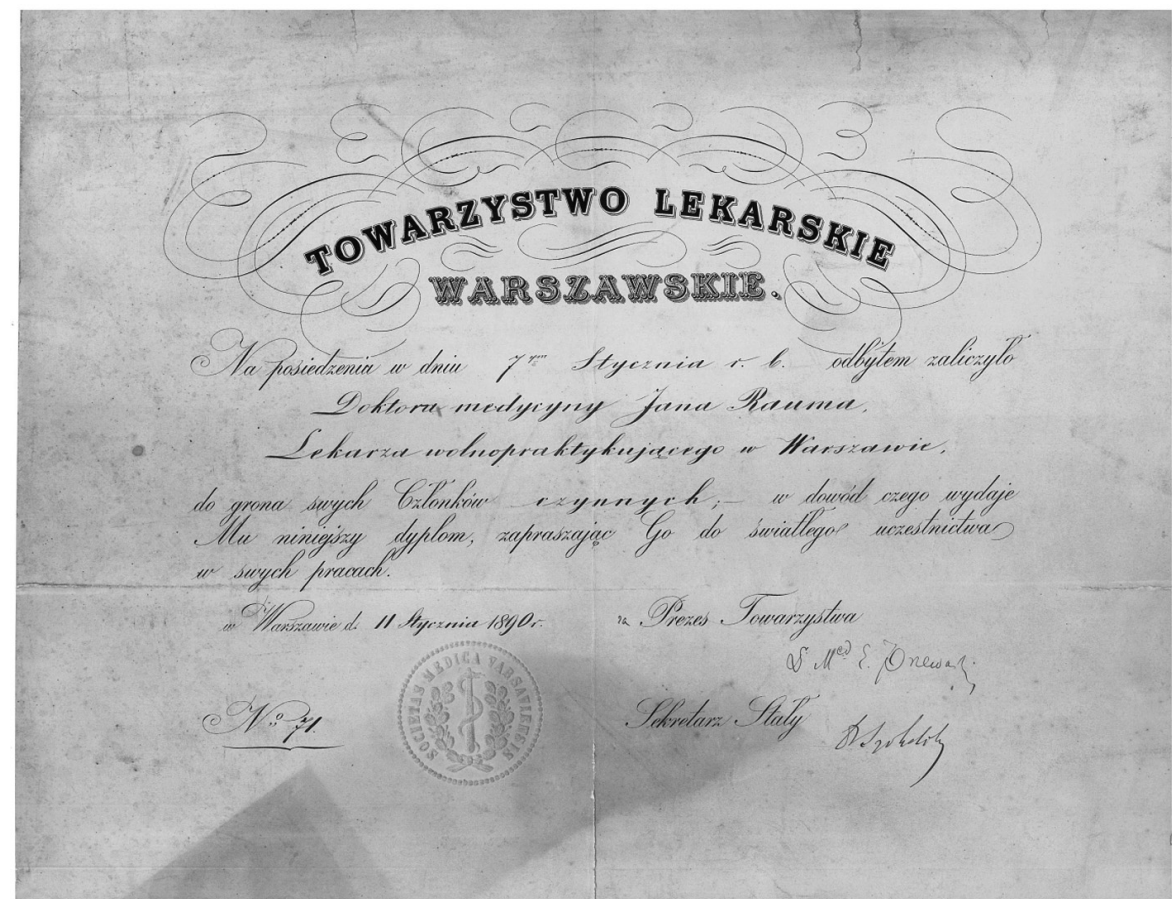

Ryc. 3. Dyplom przyjęcia dr. J. Rauma do Towarzystwa Lekarskiego Warszawskiego, $1890 \mathrm{r}$.

Źródło: Archiwum Państwowe w Warszawie.

resujące są także zeszyty zawierające bibliografię z zakresu chirurgii, chirurgii wojskowej i medycyny ogólnej, sporządzone w latach 1911-191717. Kolejne jednostki archiwalne to spisy książek medycznych znajdujących się w bibliotece dr. Jana Rauma ${ }^{18}$. Spora liczba materiałów archiwalnych przechowywanych w tym zespole jest powiązana ze szpitalem Przemienienia Pańskiego na Pradze w Warszawie i działalnością dr. Rauma jako lekarza naczelnego. Należy tu wymienić album zawierający fotografie $z$ lat 1897-1914, stanowiący swoistą dokumentację szczególnie patologicznych przypadków, obrazujących deformacje rozmaitych części ciała oraz organów pacjentów Oddziału Chirurgicznego ww. szpitala ${ }^{19}$. Album ten, zawierający 41 fotografii, został oprawiony $\mathrm{w}$ brązowe płótno, a wytłoczony złotymi literami tytuł głosi „Oddział chirurgiczny Dr. Med. Jana Raum”. Podobną za-

\footnotetext{
${ }^{17}$ Tamże, sygn. 4-7.

${ }_{18}$ Tamże, sygn. 8-10.

${ }^{19}$ Tamże, sygn. 12.
} 


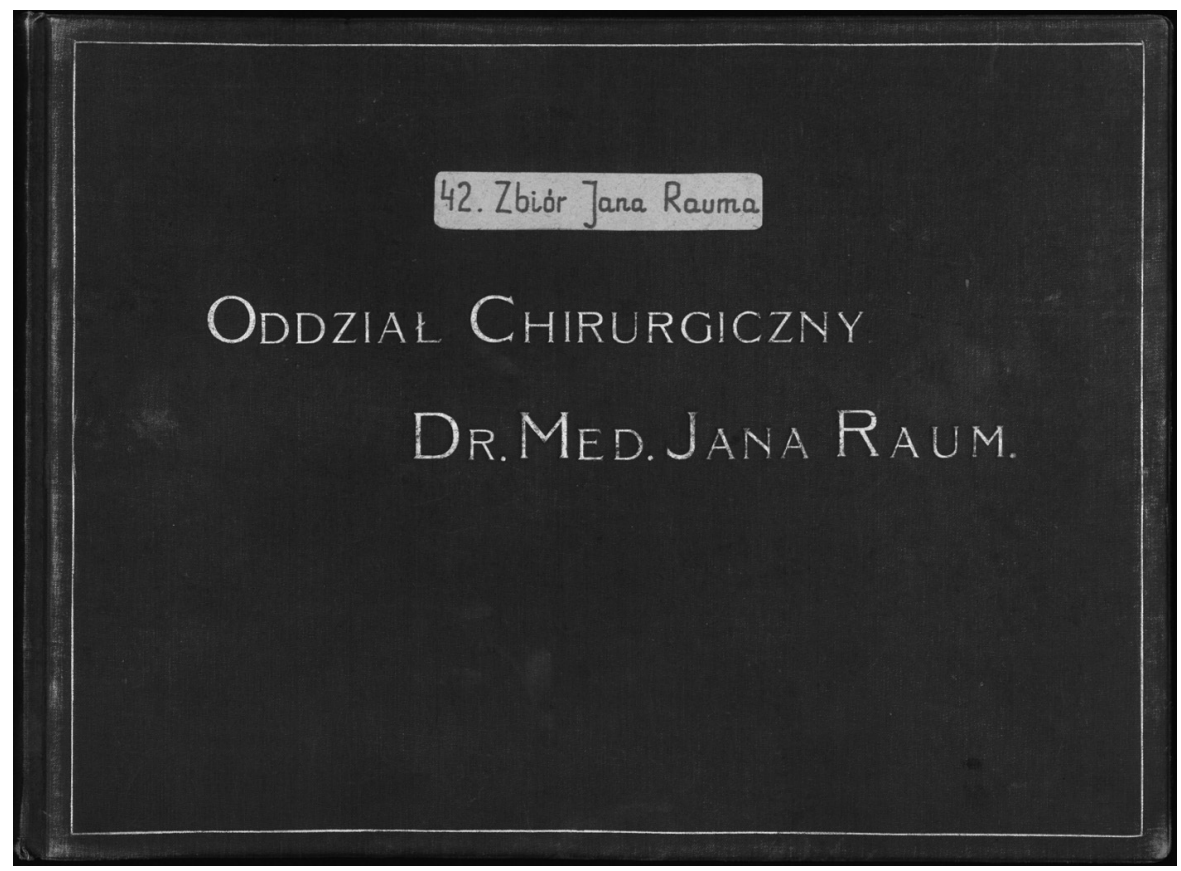

Ryc. 4. Album z fotografiami pacjentów, 1897-1914

Źródło: Archiwum Państwowe w Warszawie.

wartość można odnaleźć w teczce o sygnaturze archiwalnej 13 - zawierającej 19 fotografii o analogicznej tematyce. Jedną $z$ nich jest fotografia rentgenowska oprawiona $\mathrm{w}$ passe-partout $\mathrm{z}$ wytłoczonym ozdobnym napisem „Dr JM Judt Zakład rentgenograficzny”. Fotografia jest dodatkowo zabezpieczona bibułą, na której widnieje pieczęć „Zakład chirurgiczny i ginekologiczny w Warszawie Al Jerozolimska No 65. Telefon 30-83. Oddział Rentgenograficzny (pod kierunkiem D-ra I.M. Judta)”. W dolnej części bibuły znajduje się odręcznie napisana data 25.I.14, inicjał imienia oraz nazwisko (prawdopodobnie) pacjenta. Poniżej znajduje się pieczęć o treści „Regio renis sinistri et pars lumbalis ureteris. Calculi absunt".

Cennych informacji o szpitalu i jego naczelnym lekarzu dostarcza jednostka archiwalna zatytułowana „Dokumenty dotyczące działalności Warszawskiego Szpitala Miejskiego Przemienienia Pańskiego: obsada imienna personelu, statystyka chorych, opis sal oraz sprawy finansowe z lat 1910-1919”20. Dokumenty te stanowią skarbnicę wie-

${ }^{20}$ Tamże, sygn. 15. 
dzy o działalności ww. szpitala w okresie 1 stycznia 1915-1 stycznia 1916 r. Znajdują się tu zestawienia statystyczne, np. stan ruchu chorych Вьдомость о движеиіи больныхъ ${ }^{21}$, z uwzględnieniem następujących kategorii: płeć, ilu pozostało, ilu przyjęto, z poprawą, bez poprawy, ilu zmarło, procent śmiertelności, ilu odmówiono przyjęcia itp. Są to formularze wypełnione odręcznie. Kolejnym zestawieniem jest stan ruchu chorych z uwzględnieniem rodzaju choroby Вбдомость o движеиіи больныхъ по роду бользней ${ }^{22}$. Tak jak poprzednio, są to formularze wypełnione odręcznie. Kolejnym dokumentem zasługującym na szczególną uwagę jest projekt pisma dr. Rauma „Do Jaśnie Wielmożnego Inspektora szpitali miasta stołecznego Warszawy”23. Pismo zawiera wnioski lekarzy z Komisji szpitala Przemienienia Pańskiego dotyczące planowanego budżetu na 1917 r. Obrazuje w sposób jednoznaczny potrzeby szpitala i jego lekarzy w 1916 r. Członkowie Komisji wnioskowali o przyznanie wszystkim ordynatorom po 100 rubli rocznie każdemu na kupno biletu tramwajowego, powiększenie kredytu na prowadzenie pracowni rentgenowskiej z 300 do 1000 rubli rocznie, powiększenie kredytu na prowadzenie pracowni chemiczo-bakteryologicznej z 300 do 600 rubli rocznie, powiększenie liczby felczerów z 11 do 13, wyznaczenie jednorazowego kredytu w sumie 3845 rubli na kupno różnych utensylii dla potrzeb oddziałów szpitalnych, ustanowienie kredytu w sumie 350 rubli rocznie na lód sztuczny i naturalny dla potrzeb leczniczych. Zapotrzebowanie na lód zostało uzasadnione następująco: „Sprawa zaopatrywania szpitala w lód przedstawiała się zawsze bardzo smutnie. Do roku 1915 szpitala posiadał bardzo szczupłą lodownię, która napełniał na koszt kredytu gospodarczego, wynoszącego $150 \mathrm{rb}$ rocznie; lodu tego wystarczało tylko na potrzeby śpiżarni szpitalnej, zaś lód do potrzeb leczniczych nabywano z kredytu lekarskiego, lecz wydatek ten nie był zbyt uciążliwym, gdyż cena lodu była bardzo niewielka. Lodownia szpitalna, zburzona w 1915 roku, przez ustępujące wojska rosyjskie, nie została odbudowana z powodu wysokiego kosztu, sięgającego paru tysięcy rubli; szpital więc musi całą ilość potrzebnego lodu kupować w partyach codziennych, płacąc po 50-60 kop. [kopiejek] za pud. Do obecnej chwili w roku b. [bieżącym] lód dla szpitala kosztuje już 420 rb., a więc do końca roku wydatek na ten cel wyniesie około $500 \mathrm{rb}$. Na to szpital posiada tylko 150 rb kredytu". Następne karty zawierają spisy lekarzy, ordynato-

\footnotetext{
${ }^{21}$ Tamże, k. 10.

22 Tamże, k. 11.

${ }^{23}$ Tamże, k. 22-23.
} 
WARSZATSKI SZPITAL MIEJSKI

PRZEMIBNIENIA PAIISKIEGO

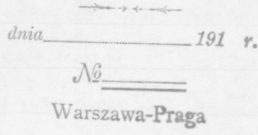

$$
\begin{aligned}
& \text { Oo } \\
& \text { Yánie Widmoñneo Paua } \\
& \text { Enspetefora cepilali uiasta } \\
& \text { stolecknego Warszawy. }
\end{aligned}
$$

$$
\text { Imas che o }
$$

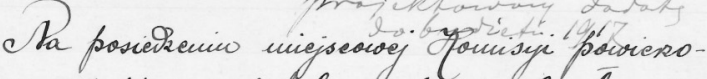
nego mej piceny vepitala lo d. 28 ubieglego suieungea roxpatrane zostaly, wigolry inuymiverio ski pp. Cetrarry, a miaccouvieie:

1) Sryanacie iseysthim ordynatorom po 100 b.

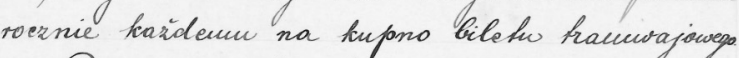

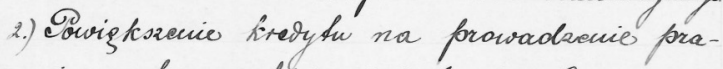
covoni reutgruowstriej z 300 do 1000 boernie.

3.) Dovighsemia kresytu na prowadracie foracouni chomierno- Gakteryologieanoj z 300 do 600,6 . roence.

\%) Dowigkszenie Ricrby felewerón \& II do 13.

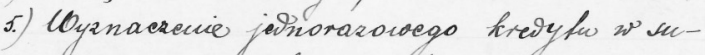
mie 3845 re na kupno rönnyeh uteusylic

dla patreb oddrialow apitaluyeh.

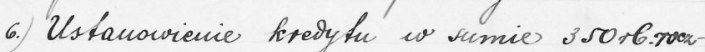
nie na lód sefueany i naturaluy dla polmele leornieryeh.

Pierusze extery wiosti of dostateernie umotywowane wralgernitach.

Figfy wrioset wasadniony soshat bardro viebstaternym wekwipowaviem of daialow do foj pony oras wrastajeceni potrebani 2 powodw statogp prepelicienin oidrialow chorymi fonad is norms, na ja kg oidaialy on uragdione.

\section{Ryc. 5. Pismo do Inspektora Szpitali Warszawskich, 1916 r.}

Źródło: Archiwum Państwowe w Warszawie. 


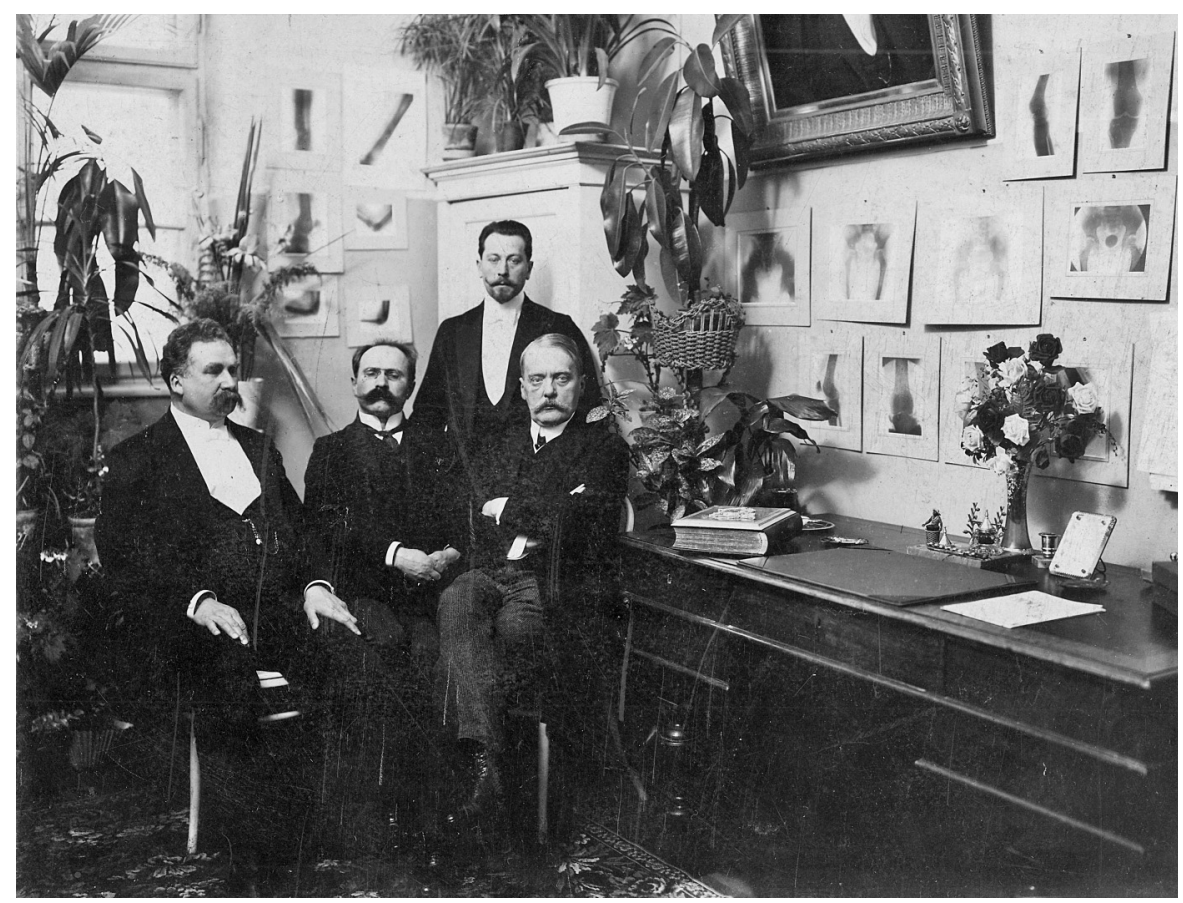

Ryc. 6. Dr J. Raum (pierwszy z prawej) w otoczeniu lekarzy, 1909 r.

Źródło: Archiwum Państwowe w Warszawie.

rów, młodszych asystentów, felczerów, a nawet listę palenisk w szpitalu i wskazania tygodniowej ilości bielizny do prania (100-200 pudów, sztuk: 5000-7000) ${ }^{24}$. Jeden z dokumentów zawiera również dokładne wskazania dotyczące rozmiarów sal szpitala Przemienienia Pańskiego na Pradze ${ }^{25}$.

W ww. jednostce archiwalnej przechowywany jest również dokument szczególny - jest to opis protokołu rozprawy toczącej się w Urzędzie Dyscyplinarnym przy Prezydencie st. m. Warszawy z dn. 27 lutego 1917 r., przeciwko doktorowi Raumowi ${ }^{26}$. Posługacz ze szpitala Przemienienia Pańskiego - Józef Rychlik zeznał, że „Bywają wypadki, że przy chorych znajdujących się pokoikach mieszka ktoś z rodziny w charakterze pielęgniarza. Osoby te [...] otrzymują jedzenie z ogólnej sali, nocują przy chorych [...]”. Zeznania te potwierdziły jeszcze dwie osoby, posługaczka szpitalna i „kuchenkowa”. Urząd Dyscypli-

\footnotetext{
${ }^{24}$ Tamże, k. 27-35v.

${ }^{25}$ Tamże, k. 36.

${ }^{26}$ Tamże, k. 61.
} 


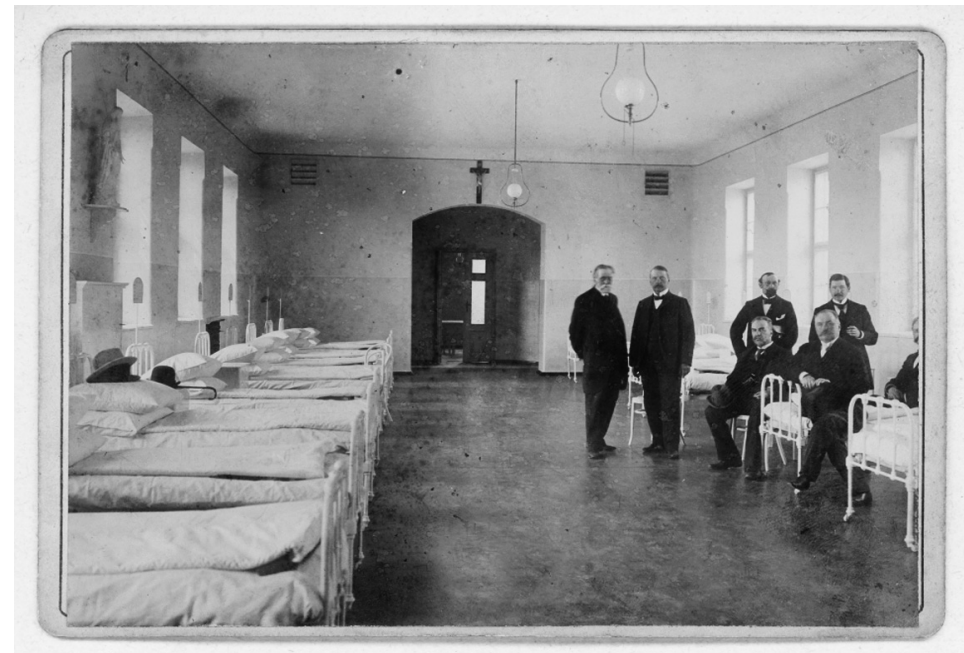

Ryc. 7. Dr J. Raum (drugi z lewej) w sali szpitalnej, b.d.

Źródło: Archiwum Państwowe w Warszawie.

narny określił zajmowanie miejsc szpitalnych przez osoby zdrowe jako niedopuszczalne, a wyjaśnienia dr. Rauma dotyczące braku instrukcji zabraniających takich praktyk za niewystarczające ${ }^{27}$. Uznano, że „naczelny lekarz szpitala Przemienienia Pańskiego dr. Roch Raum ujawnił niedość skrupulatny stosunek do przyjętych na siebie obowiązków kuratora i naczelnego lekarza”. W „Dzienniku Zarządu Miasta Stołecznego Warszawy” z dnia 23 marca 1917 r. (nr 43), w „Części Urzędowej Do wiadomości i wykonania” nakazano „udzielić napomnienia służbowego naczelnemu lekarzowi tegoż szpitala d-rowi Rochowi Raumowi, pełniącemu zarazem obowiązki kuratora, za niedość ścisłą kontrolę nad przyjmowaniem chorych"28.

Ciekawych informacji o doktorze Raumie dostarczają dwie jednostki archiwalne „Listy do Jana Rauma od osób prywatnych”29 oraz „Karty ilustrowane z korespondencją prywatną do Jana Rauma” ${ }^{30}$. Obie jednostki są dość pokaźnych rozmiarów, zawierają odpowiednio 77 i 127 obiektów. Stanowią je w większości podziękowania przesłane od pacjentów. Jednym $\mathrm{z}$ nich jest list z dnia 22 lutego 1918 r., zaczynający się od słów: „Szanowny Panie Doktorze Dobrodzieju! Racz

\footnotetext{
${ }^{27}$ Tamże, k. 62.

${ }^{28}$ Tamże, k. 66.

${ }^{29}$ Tamże, sygn. 27.

${ }^{30}$ Tamże, sygn. 28.
} 
Szanowny Pan przyjąć przy niniejszym słowa szacunku i serdecznego podziękowania, moje, i w ogóle całej rodziny, za udzielone współczucie i troskliwą opiekę nad chorym rodakiem moim Judą Działoszyńskim znajdującym się w szpitalu Przemienienia, w pokoiku pod nr 5. Wierzaj mi Szanowny Pan iż ze łzami w oczu czytamy pocieszające wiadomości iż choremu idzie dobrze chwała Bogu Wszechmogącemu, i mam nadzieję iż Szanowny Pan będzie i nadal Aniołem Stróżem z łaski Bożej który doprowadzi chorego do normalnego stanu zdrowia [...]"31. Na tym tle zupełnie odmiennie przedstawia się innego rodzaju korespondencja, w której autor oskarżał doktora Rauma o „zarozumiałość i pychę doktorską”. Uwagę zwraca już sam wygląd listu - w górnym prawym narożniku widnieje owalna podobizna młodej kobiety opatrzona podpisem „Taką panu oddałem”, natomiast w dolej części karty umieszczono kwadratowy wizerunek kobiety wykonany post mortem. W górnej części podobizny zmarłej autor listu napisał „A taką mnie pan oddał przez swoją zarozumiałą pychę doktorską”. List zaczyna się słowami „Wielmożny Dr. Raum Lekarz Naczelny Szpitala na Pradze Pan życia i śmierci nad chorymi”32. Z treści listu wynika, że autor oddał żonę do szpitala praskiego pod opiekę dr. Rauma, po wcześniejszych konsultacjach. Zgodnie z zapewnieniami doktora operacja była konieczna, ponieważ chorej groziło zakażenie. Po przeprowadzeniu operacji doktor wyjechał, natomiast pacjentka 8 dni po zabiegu dostała gorączki, a na prawej nodze pojawiła się opuchlizna. Inny lekarz - dr Antecki - postawił diagnoze „pozostawienia skrzepu z operacji i formowania się wrzodu, nadmieniając że nic radzić nie może, że musi czekać do powrotu «Naczelnego» Dra Rauma”33. Po przyjeździe lekarz stwierdził, że pacjentka cierpi na „chorobę nerki wędrującej”, czego dowodem miało być białko w moczu i spuchnięta noga. Zapewnił zaniepokojonego małżonka, że może być zupełnie spokojny, bo „to nic groźnego, tylko kuracja potrwa dłużej”34. Poprawa jednak nie nastąpiła. Dwa tygodnie później „błagałem o szczególniejszą opiekę i skupienie się nad chorą przedstawiając że to przecież Matka trojga drobnych dzieci”" ${ }^{35}$. W dalszej części listu autor obwinia doktora Rauma o nieobecność podczas konsultacji. Tłumaczył ten fakt obawą lekarza przed ujawnieniem nietrafnej diagnozy. Na prośbę małżonka lekarz pacjentki - dr Gromadzki - „wezwany

\footnotetext{
${ }^{31}$ APW, ZJR, sygn. 27, k. 61.

${ }^{32}$ Tamże, k. 10.

${ }_{33}$ Tamże, k. 11.

${ }^{34}$ Tamże.

${ }^{35}$ Tamże.
} 


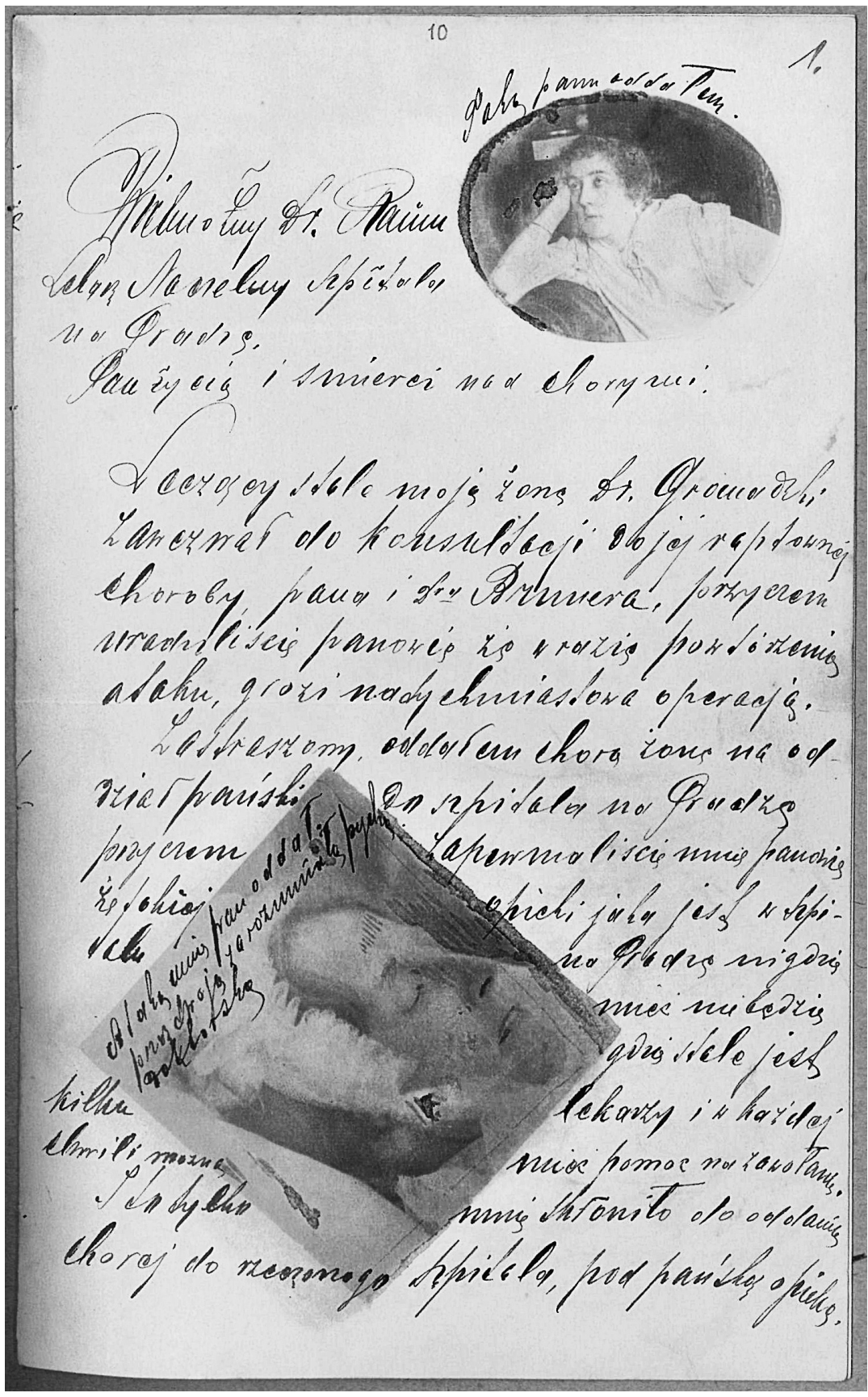

Ryc. 8. List do dr. J. Rauma, zb.

Źródło: Archiwum Państwowe w Warszawie. 
był na moją prośbę przez pana do konsultacji i to bardzo niechętnie, bo z konsultacją pan zwlekał. Uradzoną zaś powtórną operację przewlókł pan do 8go dnia, którą w dodatku po raz drugi wykonał nieudolnie i która ją zabiła" ${ }^{36}$. Autor listu zarzuca lekarzowi niepoinformowanie o innych metodach leczenia, niepowiadomienie o planowanym wyjeździe, złą diagnozę, opieszałość przy wzywaniu konsultantów i wreszcie - dwie nieudolnie wykonane operacje, z których druga zakończyła się śmiercią pacjentki. List pozbawiony jest daty, jak również danych dotyczących miejsca sporządzenia i czytelnego podpisu nadawcy. Prawdopodobnie rok później pogrążony w rozpaczy małżonek znowu napisał do dr. Rauma. Ten list także pozbawiony jest nagłówka, w lewym dolnym rogu widnieje data - 25.6.07. Autor zwraca się do lekarza w następujący sposób: „Za osierocenie trojga dzieci, przez pańską pychę wielkości, za moje nieustanne wyrzuty sumienia żem uległ wierząc zapewnieniom o braku niebezpieczeństwa i za Jej nadludzkie cierpienie, niech cię Bóg tak pokaże, abyś nie mógł więcej wydzierać rodzinom najukochańszych żon, matek i ojców!" ${ }^{77}$. Nie wiadomo, jak dalej potoczyła się sprawa zrozpaczonego męża. Pewne jest jednak, że z tego typu oskarżeniami dr Raum spotkał się jeszcze przynajmniej raz. W tej samej jednostce archiwalnej znajduje się bowiem list z 21 września 1910 r. od M. Złotkowskiego, zaczynający się do słów „Szanowny Panie Doktorze! W Mcu Maju operował Pan moją żonę na zapalenie ślepej kiszki, i operacya w zasadzie niby się udała; lecz niestety żona do obecnej pory przyjść do zdrowia nie może"38. Po opisie stanu chorej i wyniku wizyt domowych u pacjentki dr. Rauma, który nie znalazł u niej niczego niepokojącego, p. M. Złotkowski wspomina o faktycznej przyczynie choroby, jaką była „serwetka zostawiona w środku przez Pana przy operacyi, długości $1 / 2$ łokcia, szerokości 1 łokieć”39. Kontynuacją tej sprawy jest list od adwokata przysięgłego Wacława Łabęckiego (z dnia 26 września 1910 r.), w którym czytamy: „Pan Mieczysław Złotkowski powierzył mi sprawę przeciwko Panu Doktorowi, powstała z powodu nieostrożnego zoperowania Żony jego. Czy nie zechciałby Pan Doktór kwestji tej załatwić polubownie? W tym celu uprzejmie proszę Pana Doktora o łaskawe pofatygowanie się do mnie $[\ldots]$ ".. 40 .

\footnotetext{
${ }^{36}$ Tamże, k. 14.

37 Tamże, k. 17.

38 Tamże, k. 23.

39 Tamże.

40 Tamże, k. 24.
} 
W zespole „Zbiór Jana Rauma”, nr zesp. 72/1275, wśród dokumentów dotyczących dr. Rauma lub szpitala Przemienienia Pańskiego przechowywane są również archiwalia dotyczące Marii Raum. Niestety, nie wynika z nich jednoznacznie, kim była ta osoba. Pewnych wskazówek dostarczają „Pokwitowania wpłat podatku lokalowego” z lat 1903-192241, które dowodzą, że Jan Raum i Maria Raum mieszkali przy ul. Brackiej $5 \mathrm{~m}$. 2. W zachowanych dokumentach szkolnych M. Raum, przechowywanych w ww. zespole, sygn. 30, można się zapoznać z „Listem Pochwalnym Raum Maryi Uczennicy Klassy II Pensyi Wyższej Prywatnej Żeńskiej”"22, wystawionym 15 lipca 1863 r. Prawdopodobnie Maria była siostrą Jana Rauma, o czym być może świadczy fotografia rodziny Raumów (ryc. 2).

Zatem, aby poznać biogram lekarza z XIX i XX w., wystarczy zazwyczaj sięgnąć do konkretnego opracowania lub skorzystać z Internetu. Z łatwością można uzyskać dane dotyczące przebiegu kariery czy osiągnięć naukowych. Jednakże te najciekawsze informacje, zapisane $\mathrm{w}$ dokumentach przechowywanych $\mathrm{w}$ spuściznach archiwalnych po uczonych, pozwalają poznać osobowość badanej postaci, warsztat pracy, zainteresowania. $W$ przypadku archiwaliów gromadzonych i przekazanych do archiwów bezpośrednio przez tego typu aktotwórców lub ich spadkobierców, można domniemywać, że mamy do czynienia $\mathrm{z}$ dokumentami, które uczony uznał za istotne i warte zachowania. Archiwalia przechowywane w zespole „Zbiór Jana Rauma”, nr zesp. 72/1275, zostały przekazane do Archiwum w 1963 r., dopiero 45 lat po śmierci J. Rauma. Rodzi to pytania dotyczące faktycznej ilości materiałów pozostawionej przez dr. Rauma i ich dziejów w okresie 1918-1963. Niemniej jednak te zachowane dokumenty pozwalają - choćby odrobinę - poznać osobowość badanej postaci. Stanowią ilustrację dokonań doktora Rauma, umożliwiają zapoznanie się z realiami jego życia oraz poznanie tych aspektów, które nie zostały uwzględnione w oficjalnych biogramach. Są również cennym źródłem do badań historii szpitala Przemienienia Pańskiego na Pradze, w czasie gdy dr Raum był jego Naczelnym Lekarzem.

\footnotetext{
${ }^{41}$ Tamże, sygn. 24.

${ }^{42}$ Tamże, sygn. 30, k. 7.
} 


\section{Bibliografia}

\section{Źródła:}

Archiwum Państwowe w Warszawie, Zbiór Jana Rauma, nr zesp. 72/1275, 1859-1923, sygn. 1, 3, 4-10, 12, 15 (k. 10, 11, 22-23, 37-35v, $36,61,62,66$ ), 18 (k. 1-7), 20, 21, 24, 27 (k. 10, 11, 14, 17, 23, 24, 61), 28, 30 (k. 7).

Archiwum Państwowe w Warszawie, Zbiór Korotyńskich, nr zesp. 72/201, 1767-1946, sygn. XI-2061.

Archiwum Państwowe w Warszawie, Akta stanu cywilnego parafii rzymskokatolickiej św. Krzyża w Warszawie, nr zesp. 72/158, 18261934, sygn. 25 (k.373), sygn. 28 (k. 128v), sygn. 71 (k. 378).

Archiwum Państwowe w Warszawie, Akta stanu cywilnego parafii rzymskokatolickiej św. Floriana $w$ Warszawie, nr zesp. 72/1328, 1901-1919, sygn. 110, s. 469.

Archiwum Państwowe w Warszawie, Zbiór fotografii, nr zesp. 72/1606, XIX-1930, sygn. 192.

\section{Literatura:}

Dieffenbach J.F., Die operative Chirurgie, Lipsk 1845.

Zintegrowany System Informacji Archiwalnej ZoSIA, https://www. nac.gov.pl/archiwum-cyfrowe/systemy-i-infrastruktura-it/zosia/.

Internetowy Polski Słownik Biograficzny, https://www.ipsb.nina.gov. $\mathrm{pl} / \mathrm{a} /$ biografia/jan-roch-raum. 